\title{
産地別にみた烏龍茶の香気特性
}

農林水产省茶業試験場

竹 尾 忠一

\section{Characteristic Properties of Oolong Teas Made in Different Areas of China}

\author{
By Tadakazu TAKEO
}

\section{National Research Institute of Tea}

\section{1 緒言}

半発酵茶製造の際に，萎调操作のちがいが茶の香気組 成に大きな影響を与えることは既に報告した。

また包種・鳥龍茶の香気成分の特徽, さらに不発醳茶, 半発醭茶，紅茶の間でみられる香気成分組成の差につい てる報告した。

ここでは，改めて中国の福建省と台湾省（主要烏竜茶 産地）で生産されている烏龍茶について香気成分組成を 分析して，雨産地の茶の間にみられる香気特性の差につ いて検討した結果を報告する。

\section{2 試 験 方 法}

\section{1 試}

料

分析に供した茶は福建省と台湾省から1983 年度に輸入 されたものである。

\section{2 分析試料の調整}

茶 $100 \mathrm{~g}$ を $400 \mu \mathrm{g}$ のエチルデカノエート（内部標準） と共に $5 l$ の丸底フラスコに採り,これに $1.2 l$ の蒸留水 を加克，減压蒸留 $\left(40^{\circ} \mathrm{C}\right)$ を 2 時聞行った。留出して来 る水蒸気と揮発成分は，先ず 1 の承冷したナス型フラ スコ, 次に氷と塭の寒郕で冷却したトラップ, 最後に一70 ${ }^{\circ} \mathrm{C}$ に冷却した 2 本のトラップを用いて回収した。

留出液 (約 $700 \mathrm{~m} l$ ) に350 $\mathrm{m} l$ のエーテルを加兄, 食塩 を飽和量添加して，揮発成分をエーテルに転溶したのち エーテルに無水硫酸ナトリウムを加充 1 晚かけて脱水し

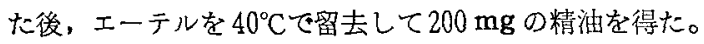

\section{3 精油成分の分析}

精油の分析は FS-WCOT カラム (PEG 20 M 染布， $50 \mathrm{~m}$, 内径 $0.33 \mathrm{~mm})$ と, FID 检知器を用い，ガスクロ マトグラフィーにより分析した。

分析は $3 \mu l$ の精油を用い, $60^{\circ} \mathrm{Cから} 180^{\circ} \mathrm{C}$ まで $2^{\circ} \mathrm{C}$ $/ \mathrm{min}$ の开温下， $30 \mathrm{ml} / \mathrm{min}$ の空菜ガス流量で行った。

分離された各成分の同定は GC-MS 法による質量分析 結果と，各成分の流出時間（tR）を，茶香気成分既報資
料と参照して行った。

また各成分の量は FID 検知器で検出された值をすと に，内部賩準物質の值を 1.0 として，その相対量で示し た。次に各成分の全精油分に対する組成比は，全精油の FID 検出值を 100 とした百分率で示した。以上の計算は 全てガスクロマトグラフィに附属しているマイクロコン ピューターによって行った。

\section{3 試 験 結 果}

図 1 (A) は福建省産鉄観音のガスクロマトグラムであ る。前報でこの茶の香気組成の特徵として, ネロリドー ル，インドールの量が多いことを報告したが，今回も高 いネロリドール，インドール量を示していた。またこの 他にベンズシアナイド，2一フェニルエタノール，ジャ スミンラクトンなど高い值を示していた。

次に図 1 (B) 治㴒省鳥龍茶, 文山のガスクロマトグラ ムを示した。この茶はゲラニオール，リナロールオキサ イド, ベンジルアルコール，2-フェニルエタノールの 量が大であり，ネロリドール，ジャスミンラクトン，イ ンドールは検出されなかった。特に文山はゲラニオール の多いのが特徴であった。

次に表 1 亿福建省鉄観音と台湾省文山の香気成分量を 表 2 K, 福建省産, 色種, 水仙, 鉄観音, 黄金桂と, 台 湾省産，文山，木梱，北埤の香気成分組成ををとめた。

一般的に言って文山，北埔のように発醉度の進んだ鳥 龍茶は, 全香気成分量が多く, 特にリナロールとそのオ キサイド，メチルサルチレート，ゲラニオール，ベンジ ルアルコール，2-フェニルエタノールの量が大であっ た。

これに対して発酵度の低い创種茶系の茶には, ジャス ミンラクトン, インドールおよびネロリドールが検出さ れるのが，包種茶と鳥龍茶との間にみられる香気組成で の特徽的な差であった。

次にがいり茶に検出される焙燒香，1-エチルピロ ールー2ーアルデヒドは方香の強い木相，北埔のような茶 

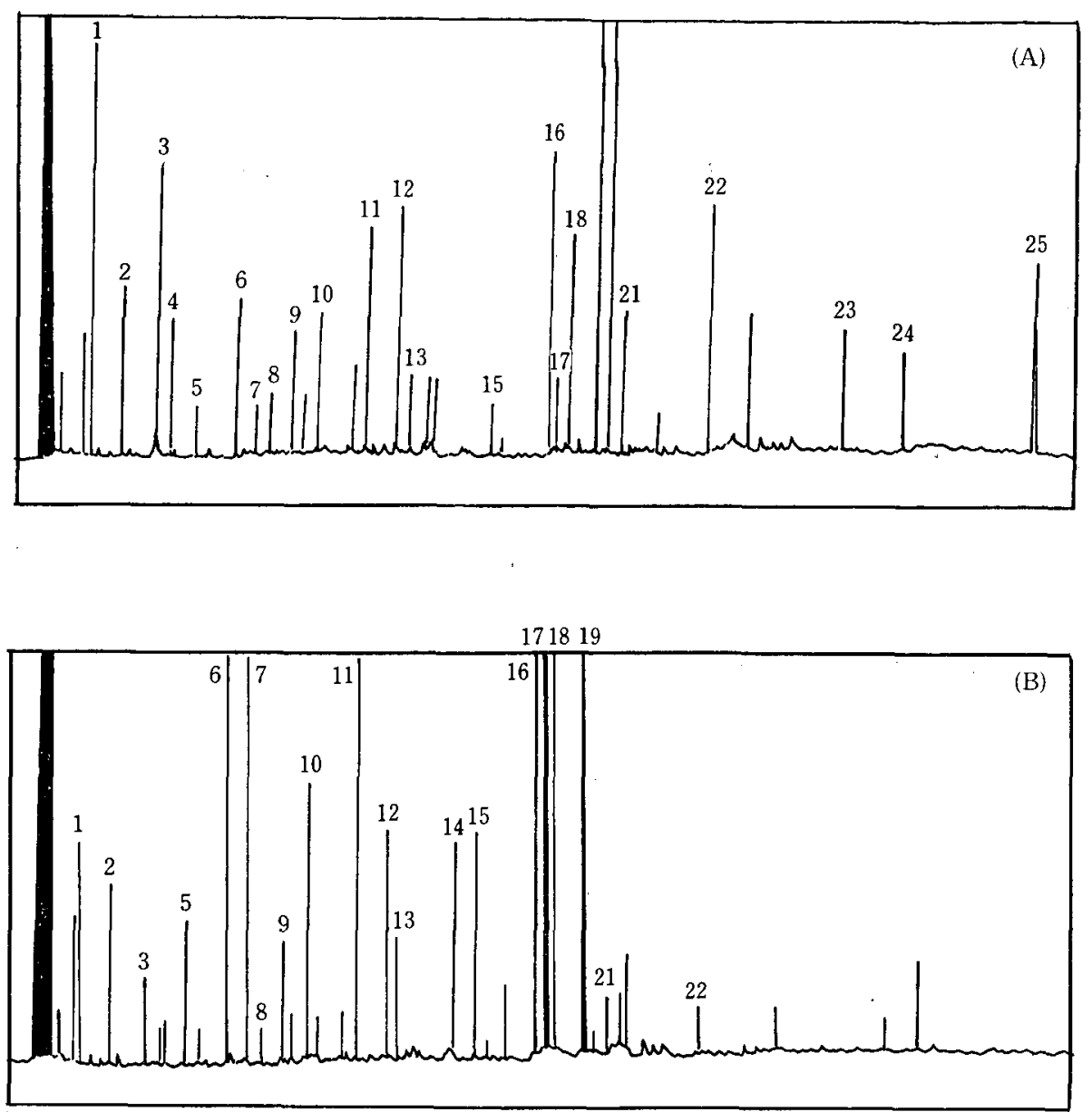

図1 鉄観音と文山の香気成分のガスクロマトグラム

\section{注 (A) 鉄観音 $\quad$ (B) 文山}

成分 1 1-ペンテン-3ーオール 2 n $\mathrm{n}$ ーアミルアルコール 3 Z-2ーペンテンー1-オール

$4 \mathrm{n}$ 一ヘキサノール 5 Zー3ーヘキセノール 6 リナロール・オキサイド（Zーフラノイド型）

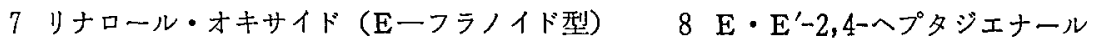

9 ベンズアルデヒド 10 リナロール (Rt 26.0分) 11 1-エチルピロールー2-アルデヒド

12 エチルデカノエート (内部標準) $13 \alpha$ チルピネオール

14 リナロール・オキサイド (ピラノイド型) 15 メチルサルチレート 16 へキセン酸

17 ゲラニオール 18 ベンジルアルコール 19 2-フェニルエタノール 20 ベシズシアネート

$21 \beta$ ターン +Zージャスモシ 22 ネロリドール 23 ジャスミンラクトン

24 ジハイドロアクチジオール 25 インドール

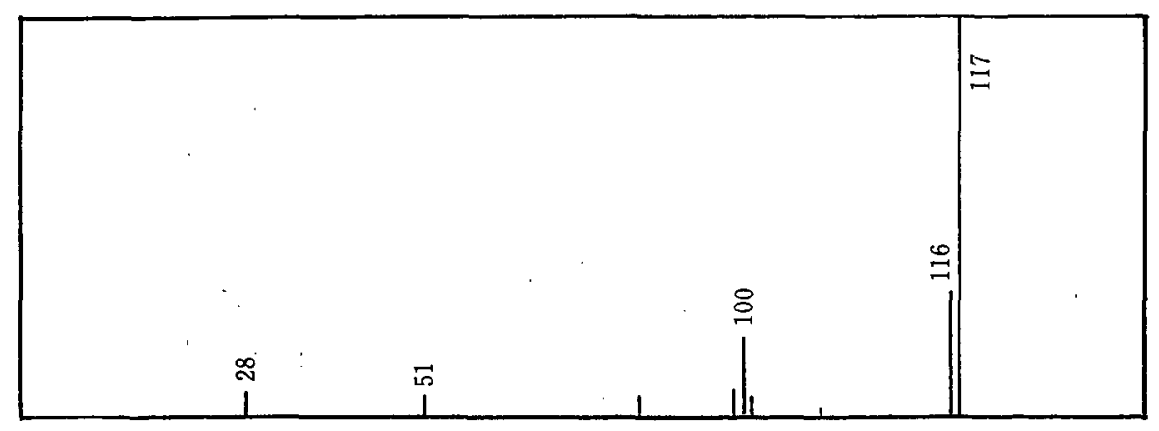

図2 鉄観音香気成分中の No. 20: ベンズシアネートの GC-MS スペクトルグラム 
表 1 鉄観音と文山の香気成分量

\begin{tabular}{|c|c|c|c|c|c|c|c|}
\hline 成 & Rt & 鉄観音 $\mid$ & 文山 & 成 & $\mathrm{Rt}$ & 鉄観音 & 文山 \\
\hline 1 -ペンテンー3ーオール & $\begin{array}{c}\min \\
9.04\end{array}$ & 0.6 & 0.2 & $\begin{array}{r}\text { リナロール・オキサイド } \\
(\text { ピラノイド) }\end{array}$ & $\begin{array}{l}\min \\
36.68\end{array}$ & 0.1 & 0.3 \\
\hline 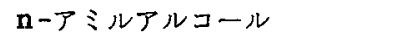 & 11.48 & 0.2 & 0.2 & メチルサルチレート & 38.72 & 0.1 & 0.6 \\
\hline Z-2-ペンテンー1ーオール & 14.06 & 0.4 & 0.1 & ヘキセン酸 & 42.97 & 1.1 & 2.4 \\
\hline $\mathrm{n}$ ヘヘキサノール & 15.12 & 0.2 & 0.1 & ゲラニオール & 43.50 & 0.2 & 6.6 \\
\hline Z-3-ヘキセノール & 16.98 & 0.1 & 0.2 & ベンジルアルコール & 44.45 & 0.8 & 3.1 \\
\hline 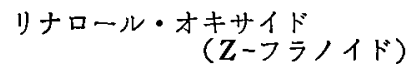 & 20.00 & 0.3 & 1.2 & 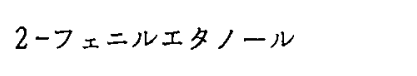 & 46.42 & 2.0 & 4.1 \\
\hline 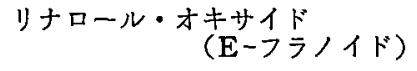 & 21.48 & 0.2 & 2.5 & ベンズシアネート & 47.28 & 1.9 & 0 \\
\hline 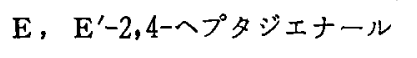 & 22.56 & 0.2 & 0.1 & 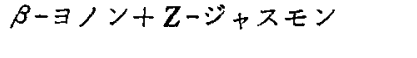 & 48.14 & 0.7 & 0.3 \\
\hline ベンズアルデヒド & 24.13 & 0.5 & 0.5 & ネロリドール & 54.70 & 0.5 & 0 \\
\hline リナロール & 25.99 & 0.5 & 1.0 & ジャスミンラクトン & 64.51 & 0.3 & 0 \\
\hline 1-エチルピロール-2-アルデヒド & 29.59 & 0.8 & 2.9 & インドール & 78.41 & 0.6 & 0 \\
\hline$\alpha$-テルピネオール & 32.72 & 0.3 & 0.6 & & & & \\
\hline
\end{tabular}

注：エチルデカノエート (内部標準) のガスクロマトグラム上のピーク面皘 1.0 とした時の各成分の面積比

表 2 香気 成 分 の 組 成 比 (\%)

\begin{tabular}{|c|c|c|c|c|c|c|c|c|}
\hline & Rt & 鉄観音 & 水 仙 & 色 種 & 黄金桂 & 文山 & 木 柵 & 北 埔 \\
\hline 1 -ペンテンー3-オール & $\begin{array}{c}\min \\
9.04\end{array}$ & 3.4 & 5.2 & 4.1 & 1.6 & 0.6 & 5.8 & 1.3 \\
\hline $\mathrm{n}$-アミルアルコール & 11.48 & 1.3 & 1.6 & 2.5 & 0.7 & 0.7 & 1.2 & 1.8 \\
\hline$Z$ Z-2-ペンテンー1-オール & 14.06 & 2.1 & 2.7 & 3.0 & 1.7 & 0.3 & 4.2 & 1.0 \\
\hline $\mathbf{n}$ ーヘキサノール & 15.12 & 1.1 & 0.5 & 0.8 & 1.1 & 0.2 & 1.6 & 0.7 \\
\hline$Z-3$ ーキセノール & 16.98 & 0.4 & 0.5 & 0.5 & 4.3 & 0.7 & 1.4 & 2.0 \\
\hline リナロール・オキサイド(Zーフラノイド) & 20.00 & 1.7 & 1.3 & 3.6 & 9.0 & 3.7 & 3.5 & 9.0 \\
\hline リナロール・オキサイド(E-フラノイド) & 21.48 & 1.0 & 0.9 & 2.2 & 2.1 & 7.6 & 14.4 & 9.0 \\
\hline 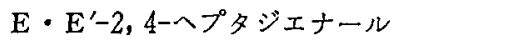 & 22.56 & 1.0 & 2.1 & 3.8 & 1.9 & 0.5 & trace & 1.4 \\
\hline ベンズアルデヒド & 24.13 & 3.2 & 3.6 & 4.5 & 1.2 & 1.6 & 2.9 & 2.5 \\
\hline リナロール & 25.99 & 2.9 & 3.1 & 2.0 & 4.9 & 2.9 & 4.3 & 4.8 \\
\hline 1-エチルピロールー2-アルデヒド & 29.59 & 4.7 & 7.6 & 4.0 & 5.4 & 8.8 & 17.2 & 19.9 \\
\hline$\alpha$-テルピネオール & 32.72 & 1.7 & 1.2 & 2.2 & trace & 1.8 & trace & trace \\
\hline リナロール・オキサイド（ピラノイド） & 36.68 & 0.9 & 0.9 & 1.7 & 13.0 & 0.9 & trace & 2.5 \\
\hline メチルサルチレート & 38.72 & 1.0 & 0.4 & 0.7 & 2.6 & 2.8 & 1.9 & 3.9 \\
\hline ヘキセン酸 & 42.97 & 6.3 & 7.4 & 13.8 & 2.1 & 7.3 & 1.3 & \\
\hline ゲラニオール & 43.50 & 1.4 & 3.9 & 2.7 & 7.5 & 19.9 & 2.6 & 13.5 \\
\hline ベンジルアルコール & 44.45 & 4.7 & 3.3 & 1.7 & 3.1 & 9.3 & 2.6 & 6.1 \\
\hline 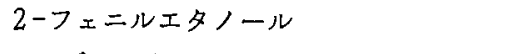 & 46.42 & 11.8 & 5.2 & 0.8 & 3.9 & 12.3 & 1.8 & 2.7 \\
\hline ベンズシアネート & 47.28 & 11.1 & 4.7 & 0.9 & - & - & - & - \\
\hline 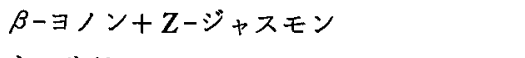 & 48.14 & 3.9 & 2.1 & 3.7 & 2.0 & 0.9 & 0.9 & 1.1 \\
\hline ネロリドール & 54.70 & 3.2 & 1.0 & 0.7 & 3.5 & - & 2.6 & - \\
\hline ジャスミンラクトン & 64.51 & 2.0 & - & 1.0 & 3.1 & - & 0.9 & - \\
\hline インドール & 78.41 & 3.9 & 4.2 & 1.4 & 3.5 & - & 4.9 & - \\
\hline
\end{tabular}


匢どその含有量が高かった。

また鉄観音, 水仙, 色種, 文山等にはへキセン酸が比 較的高い割合で含有されていた。

次に各茶間での特色をみると, 福建省産の黄金桂は鉄 観音と共に中国では芳香性に富む茶とされているが，い ずれもネロリドール，ジャスミンラクトン，インドール が多く含有されており，台湾省産包種茶の木柵にもその 傾向が認められた。

鉄観音は 2-フェニルエタノール，ベンズシアナイドの 含有比が高く，特にベンズシアナイドは鉄観音，水仙， 色種に検出される特異成分であった。図2は鉄観音の GC-MS から得られたベンズシアナイドのマススペクト ルグラムである。

黄金桂はリナロールとそのオキサイド括よびゲラニオ 一ルの含有割合が高かった。

台湾の茶では文山が，リナロールオキサイド，ゲラニ オール, ベンジルアルコール，2-フェニルエタノールの 含有比が高く，北埇もこれに準じた傾向を示していた。 木妌はリナロールとそのオキサイドの含有比に比較して ゲラニオール, ベンジルアルコール，2-フェニルエタ， 一ルの含有此の低いことで特微としてあげられた。

\section{4 考察}

半発醅茶の香気成分の特徽乞しては, 発醉度が進んだ 鳥龍茶は発酵が整度である包種茶汇比較して，テルペ ンアルコール，メチルサルチレート，ベンジルアルコー ル，2-フェニルエタノールの量が大であることがあげ られる。これは発酔が進むにつれて，これ等の成分が不 掩発性の前駆体から揮発性の成分にと変化するためと考 えられる。

一方, ジャスミンラクトンとインドールは文山, 北埔 の茶にみられるよ5に，発醇の進んだ烏龍茶では検出さ れなかった。前に報じたよらに，同一原料を用いて半発 醉茶と紅茶を製造した場合，前者ではジャスミンラクト ソ,インドールが香気成分中に多量に検出されたが，紅 茶は汪とんど検出されなかった。この結果とあわせ考克 ると、ジャスミンラクトンおよびインドールの生成は， 茶の発䤃時汇乞の発醅が強度に進む条件下では抑制され るかあるいは発酔が進む汇つれ分解するすのと考えられ る。

次に半発醉茶は 1 -エチルピロールー2ーアルデヒト，所 謂焙焼により生成する香気成分を含んでいるが，この成 分は一般には縕茶の香気成分では検出されない。的なが って1-エチルピロールー2ーアルデヒドが香㸚成分に検
出されるか否かで，半発酵茶と紅茶（発䤉萘）とを区別 することが可能と考えられる。

育地を異にした半発酵茶の香気成分には，色種，水仙， 鉄観音のようにゲラニオールよりリナロールとそのオキ サイドの組成比が高いるのと，文山，北埔の茶のように ゲラニオール組成が特に高いすのが認められたが，これ は原料として用いたチャの種間特性によるるのと考兄ら れる。

また色種，鉄観音ではベンズシアナイドが検出された が, この生成機構については興味深いものがある。

\section{5 要約}

中国, 福建省，台湾省産の鳥龍茶の香気成分組成をし らベた。

福建省産の色種, 水仙, 鉄観音, 黄金桂括よび台湾省 産木棚と，台湾省産文山，北埔との間とは，香気成分組 成に特異的な差が認められた。即ち前者は発酵度の軽度 の包種茶系の茶でこれにはジャスミンラクトン，インド 一ルが検出されたが，後者の発酵度の進んだ鳥龍荼系の 茶には両成分が検出されなかった。また発醇度の進んた 茶は発醅度の進んでない茶よりる，高沸点部の芳香成分 量が多かった。

次に半発醉茶は焙焼香気成分である。1-エチルピロ ールー2-アルデヒドが香気中に検出され，火香の強い茶 活どその量は多かった。

産地別の茶香気中のテルペンアルコール組成をみると 色種，水仙，鉄観音はリナロールの組成比が高く，台湾 省の文山，北埔はゲラニオールが多く含まれていて，そ れぞれ種間特性を示していた。

最後に本試験に用いた茶は，三井農林株式会社，株式 会社伊藤園より恵賜されたことを記して謝意に代克る。

\section{6 文献}

1) Takeo, T. : Agric. Biol. Chem., 48, 1083 1085 (1984).

2）竹尾忠一：日食工， 28，176～180（1981）,

3）竹尾忠一：農化, 56, 799 801 (1982).

4）竹尾忠一：農化，57，457 459（1983）.

5）原利男，久保田悦郎，涔田 博：茶技研，No.62， 55 56 (1982).

6) Takeo, T. : Phytochem., 20, 2145 2147(1981).

7) 竹尾忠一：農化，56，455 457 (1982).

(May 25, 1984) 